\title{
Violence Against Women Under ISIS Occupation: A Critical Feminist Analysis of Religious and Political Factors that Commodify Women's Sexuality in the War Zone
}

\author{
Zahra Hojati \\ University of Toronto, Ontario, Canada
}

\begin{abstract}
Since the end of the 20th century the Middle East (ME) has witnessed increasing war and violence and proportionally more US intervention in the region. The growth of Islamic fundamentalism, Al-Qaeda and Intermediate System to Intermediate System (ISIS) would not happen without political and economic support, posing the crucial question of who benefits, both locally and globally, from the deconstruction and reconstruction of countries involved in war. US opposition toward the founding of an Islamic state obscures the economic and political benefits it gains from ongoing conflict in the region; the profitable conflict between the US and ISIS reinforces the hegemony of both powers and perpetuates Islamic fundamentalism and Salafism in the ME rather than promote non-patriarchal ideology. I argue that ISIS claims the purpose of war is creating an Islamic state in the region and question how this claim can be ontologically coherent with Qur'an, the main resource of Islam. When ISIS occupies a region, destruction and sexual violence against women are the immediate results, and both are incoherent with a non-patriarchal reading of Qur'an. In this article, I use a critical feminist perspective to explore how establishing an Islamic state goes against Qur'an and is, therefore, un-Islamic in the way ISIS enforces its hegemony in ME. As a result, women's sexuality in particular has become a site of political economy, they are abused and /or sold in other markets for the use of ISIS soldiers. This specific religio-economic commodification of women is unique in the history of war, and the world is largely silent about it. There are brave Iraqi women, however, who use their potential and assets to support underprivileged women of the region. Their voices need amplification to gain support for their grassroots resistance to fundamentalist hegemony and political and economic disenfranchisement.
\end{abstract}

Keywords: ISIS, violence against women, Islamic fundamentalism, Salafism, women's sexuality, women's rights

\section{Introduction}

This article briefly describes women's creation in Qur'an and views the relationship between the genders with a non-patriarchal lens that provides women's rights and social justice in contrast to Islamic fundamentalism which creates more injustice and violence against women. I then discuss the social, political and economic grassroots of Intermediate System to Intermediate System (ISIS) and question the increasing violence based on Islamic fundamentalism and its association with neo-liberalism in the global state. Finally, I investigate the impact of ISIS's influence on the war zone and local women's resistance toward its hegemony

Zahra Hojati, Ph.D., The Ontario Institute for Studies in Education (OISE), University of Toronto. 
and its alliances.

\section{Qur'an's View of Women's Creation/Women's Rights}

There are extreme contradictions between a non-patriarchal understanding of Qur'an's view of women's rights and that of patriarchal, political Islam. Autocratic political Islam has a mainly patriarchal understanding of Qur'an and interprets Shar'ah (Islamic law) through an andreocentric lens, focussing on men's privilege and power. This part focus on Qur'anic concept of the creation of wo/men as it is connected to the construction of gender relationship in a society. Building on the work of Asma Barlas in her book Believing Women in Islam (2002), I would argue that gender relationships, human rights and more specifically, women's rights are based on the ontological perspective of the creation of one individual. This philosophical lens affects the social construction of gender, the way an Islamic state defines its own people and their status and rights, and the allocation of power within the nation-state more broadly. If ISIS as an extremist group claims to establish an Islamic state, its strategic approach in war zone and its behavior toward opposition causes us to question why violence is its core approach to achieving its goals? Is violence an inherent concept in Qur'an or is it in ISIS's perception of Qur'an? Following this notion, I argue that ISIS's autocratic ideology and patriarchal, selective and violent perception of Qur'an and Shari'ah lead them to create more violence against individual, and oppose to social justice so there will not be any room for different perspectives and alternatives.

Asma Barlas (2002) convincingly discusses the originality of creation of an individual in Qur'an. This is an important concept as the roots of injustice and violence against women is based on a false understanding of their creation and capability. Qur'an believes both genders are created from a single self and defines moral agency and subjectivity in terms of "ethical individualism", not sexual hierarchy (Barlas, 2002, p. 130). Morally determined action and not sexual identity defines the human subject in Islam and Qur'an treats sex as "natural and desirable for women and men, albeit within the context of a moral sexual praxis that remains within the limits prescribed by God" (Barlas, 2002, p.130). Barlas (2002) depicts that human beings, although biologically different in gender, etc., are ontologically and morally the same in as much as both wo/men originated in a single self and from the same self is created its mate (Ali, 1998; chapter 4, p. 1; chapter 6, p. 98, chapter 7, p. 198; chapter 16, p. 72). Males and females are not only indivisible in the Qur'an but they also are ontologically the same, hence equal. The reason is the two sexes were meant to coexist within the framework of mutual love and recognition, free from hierarchy and inequalities (Barlas, 2002, p. 134). Moreover, while binaries exist in Qur'an they are not in the context of superiority and inferiority, privilege and deprivation, good or bad; rather, they are a tool to better understand and recognize the nature of humans ${ }^{1}$.

Barlas (2002) continues that in the Bible there is a hierarchy of being, men created first then women. So, women are second degree citizens (pp. 140-141). Qur'an does not privilege one gender over the other: Both have the same status, and each of them are guidance for each other, both are equally capable of attaining moral individuality and both have the same function of guardianship over one another (Ali, 1998, p. 2, p. 187) .

In addition to this fundamental equality between human beings, faith and prayers cause caring about social problems (Ali, 1998, pp. 1-7, p. 107). Via this faith, the Muslim community should try to have a better

\footnotetext{
${ }^{1}$ In chapter 92, sentences 1-4 Qur'an says; By the Night as it conceals the light, By the day as it appears in glory, By the creation of male and female, the ends you strive for are diverse... (it is in terms of "charity and behaviour" it is said in the continuation of the chapter). And in chapter 49, sentence 13; O mankind, we created you from a single pair of a male and a female, and made you into nations and tribes, that you may know each other, verily the most honoured of you in the sight of Allah is the most righteous of you and Allah has full knowledge and is well acquainted.
} 
relationship to each other to pursue the path of Islam which is Tawhid; unity. Tawhid is the core of all subjects in entire Qur'an. The universe and even individuals are moving in the direction of unity, being united with nature and with other humans - and it is the Muslim's community's responsibility to facilitate this movement. Barlas (2002) states that according to Merryl Wyn Davies, "community and faith, or ummah and din are mutually defining and they give distinctive characteristics to the Islamic view of communal existence" (p. 141). It is Tawhid (Islamic) perspective that leads to defining the "community as a moral entity... whose purpose is to achieve moral balance within and between a network of relationships" (Barlas, 2002, p. 141). How these relationships are realized in practice and "translated into a particular pattern of living is the function of a din" (p. 142). To separate the moral from the social, as Muslims do when they acknowledge equality between men and women in the moral sphere while discriminating against them in the social/legal sphere, thus runs counter to a Tawhidi perspective and is, to that extent, un-Quranic (Barlas, 2002, p. 142). Moreover, at the core of Islam's view of a morally defined community is the concept of human nature (Fitra) as also moral. Human nature and life remain moral at their core and what provides the unique balance for integrative moral action is God-consciousness (tagva); it is on the basis of their tagva that the Quran differentiates between human beings, e.g. of integrative moral praxis (Ali, 1998, pp. 17-18; Barlas, 2002, p. 142). Tagwa is not gendered, and it is an ideal ethical values in Islam, which is repeated in Qur'an over 100 times and Muslims should achieve it in order to be in the God's direction. Literally, the word tagva translates as "guard" and means that a Muslim has to know how to protect him/herself from falsehood and error both conceptually and practically. So, Muslims are assessed in front of God based on their tagwa not their race, class, education, gender, sexuality or any other distinction.

This non-patriarchal reading of Qur'an exposes that the ISIS claim for the establishment of Islamic state through violence, torture, and destruction is not Qur'anic and that it also clearly opposes human rights. Contrary to Barlas, political Islam like that of ISIS reads the Qur'an through a patriarchal lens that distorts the shared creation of the genders and introduces hierarchy. This perspective gives men more privilege and power and states that women should be obedient and powerless. Men acquire the role of God on the earth, and power transfers from father to husband and even son on the family level. The rules and regulations in the countries that practice Shari'ah, or Fegh (Islamic law) are based on this rationale of no women's rights and recognition.

In the following sections, I will address the social-political power relationship that leads to the creation of ISIS.

\section{Why and How ISIS Was Created}

Since 1970s, the world gradually witnessed the growth of Islamic fundamentalism and in the 21 st century, it grows more violent via war in the Middle East (ME). Does the west also promote violence in the ME? Who are victims and who benefit from war in the region? This part will address these questions in order to argue that there is a complex matrix of socio-economic and political factors that contribute to the rise of ISIS and the perpetuation of their violent rehearsal in the Middle East rather than Islam being the sole cause and justification of the growth of ISIS and similar fundamentalist groups. In order to investigate the social-political construction of most Islamic extremist groups such as ISIS, al-Qaeda, Al-Nasr, Mojahedin, which are all related to each other, I draw your attention to the creation of al-Qaeda in 1970s in Afghanistan which in some way is the grassroots of extremism in the region.

Needless to mention, the growth of Islamic fundamentalism is coherent with the influence of 
Neo-liberalism in the ME. Under the leadership of the United States, the US and its allies fuelled globalization and (in)directly supported extremist group such as al-Qaeda for the purpose of diminishing the Soviet Union and its influence on the ME. By eliminating one of its political and economic rivals, the Soviet Union, USA sought to position itself to spread its ideology and influence across the globe. The destabilization and political fragmentation of the ME was part of a strategic plan to establish the global reach of the US hegemony.

According to Condoleezza Rice, the former United States Secretary of State, the world is looking for a new map of the ME (Nazemroaya, 2015). This new map requires the destabilization of the middle east, and the need to create more enemies in the region to validate ongoing conflict. According to Noam Chomsky (2006), imperialism seeks a new enemy because without that imperialism cannot exist and expand, so sometimes USA and its allies are fighting with drug dealers, or communism, terrorism, Islamic extremists, etc. As the need for the elimination of Soviet Union and its influence in Afghanistan became critical to American foreign policy, the need to support political Islam increased proportionally. In this regard, Saudi Arabia and Pakistan provided financial and military logistical support for al-Qaeda. Mojahedin, another name for al-Qaeda, under the ideological leadership of Molaa Omar had a very positive relationship with USA intelligence services until 1989. After the Russian exit from Afghanistan, Ben Laden, the political leader of al-Qaeda, returned to SA as a hero, a champion. Beyond that, according to Glyn Davies , senior US diplomat states that "we hope Taliban can maintain safety in Afghanistan and be a good representative for own its people and start to progress the country" (Hojati, 2014, p. 47), and the USA asked to send a diplomat to Afghanistan.

After the tragedy of 9/11 in September 2001 and the occupation of Afghanistan and Iraq in 2001 and 2003, respectively, extremist groups such as Jamaate Altouhid and Aljahdad were established mainly in Iraq with the leadership of Abu Musa al-Zarghavi (he was killed later in Iraq's war). Zarghavi was one of the al-Qaeda's members. USA attacked Iraq in the expectation of finding chemical weapons in 2003 and without finding evidence for this excuse spent over a trillion dollars and killed thousands of Iraqis. After eight years they left Iraq but still support some Sunni groups there to replace the power from the USA (Hojati, 2014). By starting war in Syria in 2013, the above mentioned groups joined other small Islamic groups and name themselves ISIS. So, their members would be from different Arabic countries. In this regard, we notice that the attack on Charlie Hebdo magazine in France in January 2015 was confirmed by al-Qaeda in Yemen. So, ISIS has relationships with all other groups in the region, from Lebanon to Altauhid and Aljahad in Syria and Palestinian military members in the Gaza Strip (Hojati, 2014, p. 48).

If US and its allies have had enormous impact on the socio-economic and political factors that helped support groups such as al-Qaeda and ISIS, what is the philosophical objective of Vahabism which influences al-Qaeda, ISIS and similar groups? The religious Vahabii leader Abdolvahab believed that Islam was diverging from its origin and asserted that Muslims must return to roots in early Islam and three of the prophet's successors. They are against Shia'a Muslims, the follower of last prophet's successor, Ali. Vahabi's followers also used the other name "Salafi", meaning they who want to go back to their ancestor's traditions; this is also ISIS's perspective. Haykel (CNN, 2025, Wood, n.d.) states that ISIS is violent Vahabism that uses selective texts that allows them to perpetrate more violence. ISIS has a project to establish an Islamic state started from Iraq and Syria. ISIS attracts lots of young people all around the world. They have a dynamic media machine, using the internet to spread propaganda and advertise their goals. Western youth might not aware of Qur'an text, and their source is only the ISIS interpretation they find online or hear repeated on the news. ISIS uses the same concepts as early Islam translated into a modern context and is not able to use the hermeneutic of the text. 
ISIS are only $0.5 \%$ of Muslims, a very small minority group but one that initiates more violence in contemporary times. ISIS is against the concept of modernity in any shape and under any name. They also introduce a concept among their followers, "takfir", which holds that any ideology that opposes them is rejected. The person who is identified as a "kafer", s/he has to be punished in a barbaric method such as beheading and slash (Hojati, 2014). So the Vahabii perspective which in different locations is called al-Qaeda or ISIS use selective and violent concept from Qur'an and legal text. This is the reason that they easily behead any opposition, and rape or enslave women who they capture in war zone (Susskind, 2014).

In the end, we should notice that in 1951 the USA established its military site in SA through a military contract that was signed between the two countries to support each other. Critical feminist activists and scholars confess that SA follows Vahabism and its rules and regulations are against human/women's rights but there are no voices speaking out via western media. Julian Asang, the Wikileaks's manager, states that SA is a state that by censoring media continues its violence such as beheading people - it is a dangerous regime not only for its own people but also for the whole world (Shokri, 2015, p. 4).

\section{Muslim Women's Sexuality in War Zone}

ISIS is the result of at least 200,0000 murders and millions of people displaced and divorced from their hopes and dreams. In this part I will discuss ISIS violence against women in the occupied territory, while addressing the attraction of ISIS to young western women; in the last part, I will address women's resistance toward US occupation and ISIS tyranny. In this part, the role of Iraqi women is not envisioned as victim to violence but as resistance to US attack and ISIS torture. One of my main concerns in this part is asking what the location of feminist activists in the war zone is?

Unfortunately, Iraq and Syria had become incubators for transnational so-called jihad ${ }^{2}$ and religious hate. Under the name of jihad and sex jihad, Muslim women's voices and rights are eliminated. This violence is not random. Muslims are killed and raped by other Muslims. Rape is a terrifyingly common weapon used to terrorise and control communities during warfare. As Iraq descends into war, women are not only on the frontlines, they are the battlefield. But here is the part that too many media reports have missed: They are not just victims, they are critical first responders (Susskind, 2014). According to the news, the first day that ISIS entered the city Mosul in Iraq, a gunman leaned out a car's window and pointed out women in the street to cover themselves. The gunman's perspective on women's bodies should not be viewed as a singularity; it demonstrates a broader viewpoint and reveals that this group will eliminate women from public sphere as well as be violent toward them in the private sphere. Yet, only recently has the topic been treated with the seriousness it warrants. On the day that ISIS conquered Mosul, world leaders were in London for a meeting to address the scourge of war-time rape. Now, government's commitment to protecting women in war zones from sexual violence is again being tested (Susskind, 2014).

To understand this, we need to rewind to the worst days of the sectarian violence that erupted under the US occupation. In those bloody years from 2003-2008, the US dismantled Iraq's secular government bureaucracy. It imposed a system that allocates political power according to religious sect, turning a theological difference into a dangerous political divide (Susskind, 2014). Following this divide, religious extremists who seek the establishment of the Islamic state in a more patriarchal perspective could find their opportunity in the

\footnotetext{
${ }^{2}$ In early Islamic history prophet Muhammed used the term jihad to unit Muslim against opposition. And war was a minor jihad, prophet Muhammad states controlling one's inner self is the biggest jihad to the path of being a good Muslim.
} 
country to impose its violence against women.

Under US rule, sectarian militias launched a campaign of terror, hunting down activists, artists, academics and anyone who challenged their vision of society. Women were targeted specifically. In 2008, on a billboard on the walls in Basra it was written "Your makeup and your decision to forgo the headscarf will bring you death" (Susskind, 2014). Women were not safe at home either, especially after the US rulers empowered political parties and endorsed "honour killing"3 as a religious duty for families to police women's behavior, So, neo-liberalism went hand-in-hand with Islamic fundamentalism to restrict women's right and voices. When ISIS enters a location in Iraq, such as Khalaf's village, Khocho, and Qiniyeh kill men and enslave women, rape them and sell them to other countries such as Syria or divide them among jihadists (Spencer, 2014). Five thousand men may have been shot dead and bulldozed into mass graves, and 7,000 women held in detention centres to be offered as slaves (Spencer, 2014). As discussed in previous sections of this article, ISIS justifies its barbarian behaviour by connecting it to the early history of Islam. Although there is no valid quotation in Qur'an to approve their violent behaviour, ISIS dogmatic understanding gives them legitimacy to use a concept such as Jihad to establish an Islamic state and kill other Muslims too. Raped and/or slaved women are mostly from the Yazidi group which is supposed to be the follower of Zoresterian, an old Persian religion dating from before Islam among Iranians. It is sad to mention that the western followers who join ISIS and leave the west to act as a wife for ISIS in a sex jihad ${ }^{4}$, are contributing to producing a new concept in the contemporary history in war zone. These brides, under the concept of sex jihad, also support this violence against women. In contemporary time, it is reported 500 western young women joined ISIS as bride housewives (Eposti, 2015). The reason behind joining sex jihad is that western youth suppose ISIS is doing jihad, a holy war to eliminate koffar, so women should support them and fulfil them in battlefields. The women's role is also a jihad but in specifically sexual terms. So, sex jihad is a new terminology that ISIS created to please first its jihadists in the war zone and second to justify women's willingness to be part of this jihad (Eposti, 2015). Ross Frenett, one of the authors of the report "Housewives in a war zone", points to the fact that western jihadist brides, despite their jihadist goals and propaganda slogans, remain "deeply Western". One of the paradoxes of their world is that they profess their commitment to their version of "Islam" and their support for atrocities such as mass beheadings, torture, and violence in very relatable language. Frenett says, "It's a bizarre mix of western teenage speak with a massive amount of brutality" (Eposti, 2015). As the result, the expansion of Islamic fundamentalism and its connection with western power to change the map of the Middle East and establish new states, new territories, not only endangers local people's lives but also affects the lives of people in the west. ISIS is looking to establish its own state in Iraq and Syria, but how would it happen without political, economic, and military support?

In response, Iraqi women have mobilised in unprecedented ways since 1990s by the intervention of US in war golf. For instance, as the result of hundreds of thousands of women were widowed by consecutive wars, and genocide executed by Saddam's army, economic sanctions (by USA) spread out poverty to unthinkable extends where every widow finds herself responsible of a family with no sort of support or social insurance. Increasing honor killings, and absence of supremacy of law, allowing Islamist misogynist practices which the ruling Baath party chose to apply by committing mass killings on women (OWFIa, 2015), local women's

\footnotetext{
3 The concept of Honor Killing does not exist in Qur'an. It means if a woman does any action which is not proper for her families, they would kill her! It is related to shame for family's reputation.

${ }^{4}$ Sex jihad is a new concept which is created in contemporary war zone.
} 
movement started to establish on 8th of March 1992 in North of Iraq. It was Independent Women's Organization (IWO) which funded by volunteering individual. IWO has extended its influence to international locations that attracted masses of Iraqi refugees. It is represented now in Canada, England and Australia (OWFIa, 2015). IWO established in North of Iraq mainly service a population of five million in Iraqi Kurdistan. They encounter 4,000 honor killing between 1990-1999, hundreds of bunt women, tens of honor driven mutilations against women, thousands of circumcised (genitally mutilated) girls yearly till this present day. IWO called for international support in western countries in their struggle against Islamist influence on violence against women (OWFIa, 2015).

Following IWO Yanar Mohammed as a co-funder and director of the Organization of Women's Freedom in Iraq, (OWFI), established a new organization in 2003 (after the occupation of Iraq by USA). She supports left wing ideology, secularism and is against political Islam. She attended the Women Stop War conference in The Hague, she describes the current situation in Iraq. "The country is under a prevailing culture of militias, which have the upper hand... They say, 'It's either USA or ISIS"' (OWFIb, 2015). Mohammed continues civil society is sandwiched between Shia and Sunni extremists, and argues a secular approach is the only way to resolve the conflict in her country (OWFIb, 2015 ). She continues the country is under something that's nothing less than a civil war, where the Iraqi government, led by the Islamist Shia parties, is attacking the ISIS-conquered cities, and the massacres are underway, both sides. And we, in the Organization of Women's Freedom, are trying to get to the women who are escaping the enslavement of ISIS, and opening shelters for them. But in general, the country is under a prevailing culture of militias, which have the upper hand. And nobody can be complaining about it, because whenever we say anything, they say, "But we are the ones who are liberating you from ISIS. It's either us or ISIS" (OWFIb, 2015). So, although OWFI is under conditions of military occupation, civil war and fundamentalist witch-hunts, spoke out against policies that created sectarian divisions and fuelled gender-based violence (Susskind, 2014). They created a network of underground safe houses for women fleeing violence at home and in the streets. As men leave to fight, tens of thousands of women are becoming heads-of-households, responsible for meeting the urgent needs of their vulnerable families and communities. Meanwhile, in communities occupied by ISIS, fighters have kidnapped women from their homes, telling their families that these attacks are justified by a "sexual jihad". Four women committed suicide after militants raped them (Susskind, 2014).

In addition, OWFI, with Madre and other international allies, is rallying resources to provide shelter, medical care and humanitarian aid to women who have survived rape or have been forced to flee ISIS-controlled areas. OWFI is providing food aid to women who are heads of households, who can then reach the most vulnerable displaced people, including children and the elderly. Even in Anbar Province, where ISIS flags are flying high, OWFI is there, offering protection and aid to those who are most at risk of sexual violence. These are the women who never stopped organising through the years of invasion, occupation and civil war. Once again, they are facing down brutality (Susskind, 2014). OWFI activists in Iraq is similar to RAWA (Revolutionary Association of Women of Afghan) (Jiwani, 2005) in Afghanistan against al-Qaeda's influence . Local-conscious women try to produce women's perspective towards their rights and voices and combat the influence of Islamic fundamentalism as well as western domination in their region.

From the other side, international women's rights via the Untied Nations get the position of supporting women in war zone. In this regard, Angelina Jolie, the Hollywood actress/director and international women's rights campaigner, created a centre for collaboration with former UK foreign secretary William Hague, London 
School of Economics and the UK government to consider violence against women in war zone as a security issue. This centre contains key thinkers, activists, policymakers and academics together in order to better tackle global problems such as the prosecution of warzone rapists and women's engagement in politics. The purpose is for "the empowerment of women to be the highest priority for the finest minds, in the best academic institutions" (Topping, 2015). A four-day meeting hosted by Jolie and Hague in June 2014 , as part of the UK government's Preventing Sexual Violence in Conflict initiative, resulted in a protocol signed by 151 countries and the LSE's centre on Women, Peace and Security is the latest step in trying to combat the use of rape as a weapon of war (Topping, 2015). Although we should not undervalue international research and effort to support women in war zone, questions remain as to how the effort of this centre can be coherent or cooperative with local women's activities. What is the real expectation of the LSE centre? Can they be accepted by local activists, can they expose the source and roots of violence in the global world? How can the government of UK be part of war zone while also supporting women in war zone ? How can governments with conflicting interests in the ME bring about women's safety and security in war zone? Moreover, what is the position/strategy of feminist activists and academics in the world regarding the center activities and also local activities?

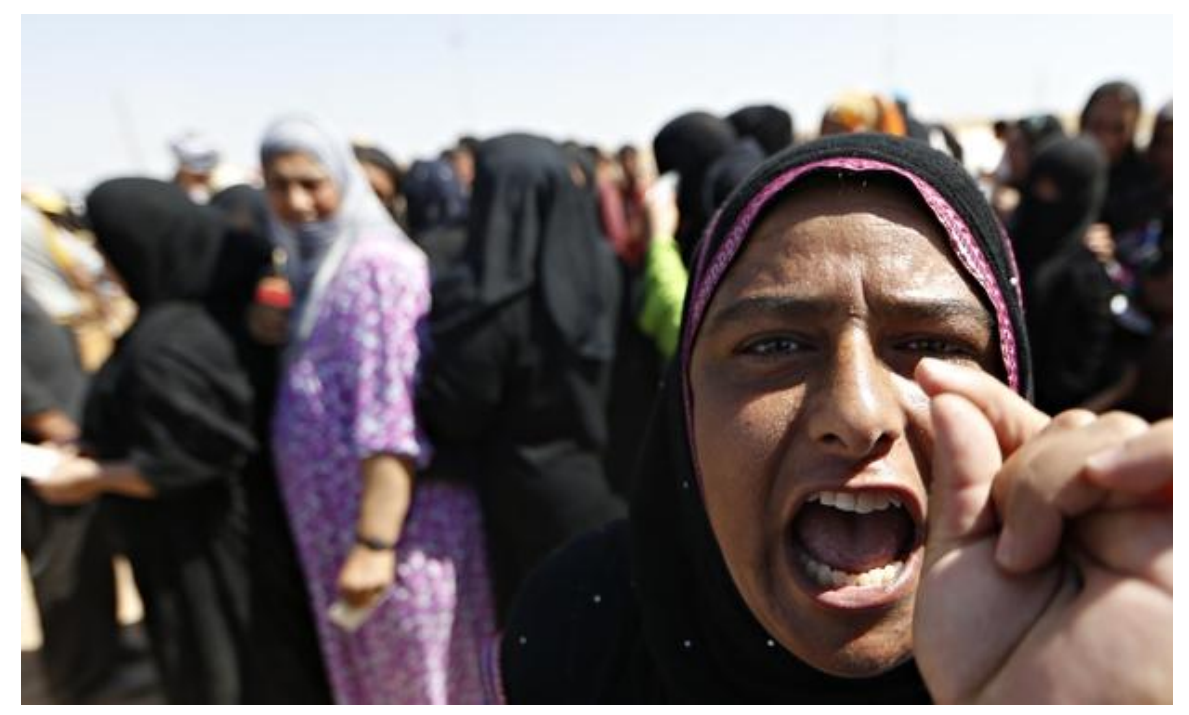

Figure 1. The women's resistance in Iraq.

The militants are using rape and brutality to control women who have not stopped mobilising since the US occupation. This picture shows the women's resistance in Iraq (see Figure 1).

\section{Conclusions}

In this article, I contextualize the roots of ISIS's creation and hegemony in the M.E from a critical feminist perspective. The growth of such extremist ideology would not happen without political and economic support both in and outside of the region, and war among different branches of Muslims results in murdering, torturing, and raping of their citizens. Women's sexuality become a site of control and abuse, and so the victimization of women must be an issue for all people who seek to establish justice and women's rights not only locally but also globally. As a result, we need to encourage collective awareness and support for disadvantaged women and children to achieve peace and human's rights. 


\section{References}

Ali, A. Y. (1998). Modern English translation of the Holy Qur'an: Meaning \& commentary. Kansas City, MO: Manar International.

Barlas, A. (2002). The Qur'an, sex/gender and sexuality: Sameness, difference, equality. In Believing Women in Islam: Unreading Patriarchal Interpretation of the Qur'an. (pp. 129-166). Houston: University of Texas Press.

Chomsky, N. (2006). A world without war. In R. A. Rhoades \& C. A. Torres (Eds.), The University, state, and market: The political economy of globalization in the Americas (pp. 39-59). Stanford, CA, Stanford University Press.

CNN. (2015, February 23). Bernard Haykel: A lot of Muslims are embarrassed by ISIS (video file). Retrieved from https://www.youtube.com/watch?v=PBPJxZ_GPbQ

Eposti, E. (2015, January 30). Housewives in a war zone: The reality of life under ISIS. Middle East Monitor. Retrieved from https://www.middleeastmonitor.com

Hojati, Z. (2014, February 19). The globalization of violence: Growth of Islamic fundamentalism and secular Fundamentalism. Iran Star Magazine, 21(1046), 46-48.

Jiwani, Y. (2005). The Great White North Encounters Sept 11: Race, gender and nation in Canada's National Daily, The globe and mail. Social Justice, 32(4), 50-69.

Khedery, A. (2014, August 22). How ISIS came to be? Retrieved from http://www.theguardian.com/world/2014/aug/22/syria-iraq-incubators-isis-jihad.

Nazemroaya, M.D. (2015, May 19). Plans for redrawing the Middle East: The project for a "New Middle East". Retrieved from http://www.globalresearch.ca/plans-for-redrawing-the-middle-east-the-project-for-a-new-middle-east/3882

OWFI. (2015a). Organization of women's freedom in Iraq. Retrieved from http://www.owfi.info/EN/about/

OWFI. (2015b, May 9). Iraqi activist describes "massacres left and right" as civil society resists takeover by ISIS. Retrieved from

http://www.owfi.info/EN/article/iraqi-activist-describes-massacres-left-and-right-as-civil-society-resists-takeover-by-isis/

Shokri, A. (2015, June 25). Saudi Arabia in gerdab Wikileaks. Shahrvand Magazine, 24(4), 56.

Spencer, R. (2014, October 14). ISIS jihadists offer Islamic justification for taking thousands of Yazidi women as sex slaves.

National Post. Retrieved from

http://news.nationalpost.com/news/world/israel-middle-east/isis-jihadists-offer-islamic-justification-for-taking-thousands-ofyazidi-women-as-sex-slaves

Susskind, Y. ( 2014, July 3). Under ISIS, Iraqi women again face an old nightmare: Violence and repression. The Guardian. Retrieved http://www.theguardian.com/global-development/poverty-matters/2014/jul/03/isis-iraqi-women-rape-violence-repression

Topping, A., \& Borger, J. (2015, February 10). Angelina Jolie opens UK centre to fight warzone violence against women. The Guardian. $\quad$ Retrieved from http://www.theguardian.com/uk-news/2015/feb/10/angelina-jolie-opens-london-centre-to-combat-warzone-violence-againstwomen

Wood, G. (2015, March). What ISIS really wants. The Atlantic. Retrieved from http://www.theatlantic.com/features/archive/2015/02/what-isis-really- wants/384980/ 